\title{
Analysis of 13 Alternaria mycotoxins including modified forms in beer
}

\author{
Sophie Scheibenzuber ${ }^{1} \cdot$ Fabian Dick $^{1} \cdot$ Stefan Asam $^{1}$ [D $\cdot$ Michael Rychlik $^{1}$
}

Received: 17 November 2020 / Revised: 12 February 2021 / Accepted: 16 February 2021 / Published online: 5 March 2021

(c) The Author(s) 2021

\begin{abstract}
A multi-mycotoxin LC-MS/MS method was developed to quantify 13 free and modified Alternaria toxins in different beer types by applying a combination of stable-isotope dilution assays (SIDAs) and matrix-matched calibration. With limits of detection (LODs) between $0.03 \mu \mathrm{g} / \mathrm{L}$ (alternariol monomethyl ether, AME) and $5.48 \mu \mathrm{g} / \mathrm{L}$ (altenuene, ALT), limits of quantitation (LOQs) between $0.09 \mu \mathrm{g} / \mathrm{L}$ (AME) and $16.24 \mu \mathrm{g} / \mathrm{L}$ (ALT), and recoveries between 72 and 113\%, we obtained a sensitive and reliable method, which also covers the emerging toxins alternariol-3-glucoside (AOH-3-G), alternariol9-glucoside (AOH-9-G), alternariol monomethyl ether-3-glucoside (AME-3-G) and alternariol-3-sulfate (AOH-3-S) and alternariol monomethylether-3-sulfate (AME-3-S). Furthermore, 50 different beer samples were analyzed, showing no contamination with Alternaria toxins apart from tenuazonic acid (TeA) in concentrations between $0.69 \mu \mathrm{g} / \mathrm{L}$ and $16.5 \mu \mathrm{g} / \mathrm{L}$. According to this study, the exposure towards TeA through beer consumption can be considered as relatively low, as the threshold of toxicological concern (TTC) value of $1500 \mathrm{ng} / \mathrm{kg}$ body weight per day might not be reached when consuming reasonable amounts of beer.
\end{abstract}

Keywords Alternaria mycotoxins $\cdot$ Tenuazonic acid $\cdot$ Modified toxins $\cdot$ Stable isotope dilution assay $\cdot$ Beer

\section{Introduction}

With a per capita consumption of over $100 \mathrm{~L}$ of beer, Germany is among the top five countries with the highest beer consumption worldwide (World Health Organization 2018). Generally, an increase of beer consumption, on the one hand, and, on the other hand, a rising occurrence of mold growth on agricultural commodities due to unfavorable weather conditions can be observed. Both factors lead to concern in terms of mycotoxin exposure from beer consumption, as the main ingredients barley and wheat are often prone to fungal infection (Logrieco et al. 2009; Ostry 2008). Consequently, mycotoxin concentrations in beer should be monitored regularly to guarantee a safe product as toxins can be carried over from the grain into the final product. This was already shown for some Fusarium mycotoxins. Toxin concentrations generally increased during the malting step; however, the transfer rate into the beer was compound dependent (Habler et al. 2016, 2017). Although Fusarium mycotoxins are often

Stefan Asam

stefan.asam@tum.de

1 Chair of Analytical Food Chemistry, Technical University of Munich, Freising, Germany considered the most critical risk factor during brewing, the malting process could also lead to production of Alternaria mycotoxins due to ideal growing conditions for Alternaria spp. (Bottalico and Logrieco 1998; MacLeod and Evans 2016). However, the behaviour of Alternaria toxins during the brewing process is still unclear, which makes further conclusions about mycotoxin transfer into the final product impossible.

In the field of Alternaria mycotoxins, the most frequently analyzed toxins are alternariol $(\mathrm{AOH})$, alternariol monomethyl ether (AME), tenuazonic acid (TeA), altertoxins I and II (ATX I and ATX II), stemphyltoxin III (STTX III), tentoxin (TEN), altenuene (ALT) and alterperylenol (ALTP). However, also some modified forms of those toxins were detected recently and evoked increased attention in the last few years. These modified mycotoxins should also be included in analytical methods, because they might be able to release their parent toxin during digestion and therefore contribute to the total exposure towards mycotoxins (EFSA 2011). In the case of Alternaria toxins, some compounds are modified by the fungus itself, e.g. AOH-3-sulfate (AOH-3-S) and AME-3-sulfate (AME-3-S), while others are modified by the metabolism of the infected plant, e.g. AOH-3-glucoside (AOH-3-G), AOH-9-glucoside (AOH-9-G) and 
AME-3-glucoside (AME-3-G) (Soukup et al. 2016). Chemical structures of these compounds are shown in Fig. 1.

Until now, only a limited amount of data regarding Alternaria toxins in beer can be found in literature. Modified Alternaria toxins have not been analyzed in this matrix at all, yet. Furthermore, the presence of AOH, AME, TeA and TEN in various wine and juice samples shows the general ability of Alternaria toxins to be carried over through various food processing steps, which makes the analysis of beer particularly interesting (Broggi et al. 2013; Fan et al. 2016; Zwickel et al. 2016). In a study from 2010, Siegel et al. (2010) tested 43 beer samples for their TeA concentration and found an average TeA content of $11 \mu \mathrm{g} / \mathrm{L}$, which seems reasonable as TeA is highly water soluble and might easily be carried through the brewing process. In another study conducted by Bauer et al. (2016), all 44 tested beer samples were positive for $\mathrm{AOH}$ with the highest concentration being $1.6 \mu \mathrm{g} / \mathrm{L}$. Although these values seem to be relatively low, especially the $\mathrm{AOH}$ concentration can be critical when regarding the threshold of toxicological concern (TTC) value of $1.5 \mathrm{ng} / \mathrm{kg}$ body weight per day, which emphasises the importance of further studies in this field (EFSA 2011).

To evaluate the mycotoxin contamination in beers from German supermarkets and a local beer store, we aimed to develop a multi-mycotoxin liquid chromatography tandem mass spectrometry (LC-MS/MS) method to detect free and modified Alternaria toxins in different beer types. Besides the above-mentioned reports about the occurrence of TeA and AOH in beer (Siegel et al. 2010; Bauer et al. 2016), there is limited analytical data for this matrix available up to now.<smiles>[R]Oc1cc(C)c2c(c1)oc(=O)c1c(O)cc(O)cc12</smiles>

$$
\begin{aligned}
\mathrm{R}_{1} & =\mathrm{H} \text { : alternariol }(\mathrm{AOH}) \\
& =\mathrm{SO}_{3}: \mathrm{AOH}-3-\text { sulfate } \\
& =\mathrm{C}_{6} \mathrm{H}_{12} \mathrm{O}_{6}: \mathrm{AOH}-3 \text { - glucoside }
\end{aligned}
$$<smiles>[R3]Oc1cc(C)c2c(c1)oc(=O)c1c(O)cc(OC)cc12</smiles>

$$
\begin{aligned}
\mathrm{R}_{3} & =\mathrm{SO}_{3}: \mathrm{AME}-3 \text { - sulfate } \\
& =\mathrm{C}_{6} \mathrm{H}_{12} \mathrm{O}_{6}: \text { AME - } 3 \text { - glucoside }
\end{aligned}
$$<smiles>CC(C)C[C@H](NC(=O)[C@H](C)N(C)/C(=C/c1ccccc1)C(=O)NCC(=O)N(C)C)C(=O)O</smiles>

tentoxin<smiles>COc1cc(O)c2c(c1)C1=C[C@H](O)[C@@H](O)C[C@]1(C)OC2=O</smiles>

altenuene $\begin{aligned} \mathrm{R}_{2} & =\mathrm{CH}_{3}: \text { alternariol monomethyl ether (AME) } \\ & =\mathrm{C}_{6} \mathrm{H}_{12} \mathrm{O}_{6}: \mathrm{AOH}-9 \text { - glucoside }\end{aligned}$<smiles>CC[C@H](C)[C@H]1NC(=O)C(C(C)=O)=C1O</smiles>

tenuazonic acid<smiles>O=C1CC[C@H]2c3c1ccc(O)c3-c1ccc(O)c3c1[C@@H]2[C@H](O)CC3=O</smiles>

altertoxin I<smiles>O=C1CC[C@]2(O)c3c(ccc(O)c31)-c1ccc(O)c3c1C2C1CC1C3=O</smiles>

altertoxin II<smiles>O=C1C[C@@H](O)[C@]2(O)C=CC(=O)[C@@H]3c4ccc(O)c1c4[C@@]32O</smiles>

alterperylenol<smiles>O=C1C=CC2(O)c3c4ccc(O)c3Oc3ccc(O)c2c3C4C2OC2C1=O</smiles>

stemphyltoxin III

Fig. 1 Chemical structures of 14 Alternaria mycotoxins including some modified forms. Due to instable standard solutions, the toxin stemphyltoxin III (STTXIII) was only qualitatively included in this study 
Also, the modified toxins AOH-3-G, AOH-9-G, AME-3-G, $\mathrm{AOH}-3-\mathrm{S}$ and AME-3-S are only rarely included in analytical methods and were so far only determined in tomato products, cereal, fruit and vegetable juices as well as sunflower seed oil (Puntscher et al. 2018; Walravens et al. 2014, 2016). This study aims to get a better insight in Alternaria mycotoxin exposure through beer consumption and might give a first overview on toxins that can be carried over into beer during the brewing process.

\section{Materials and methods}

Chemicals and reference standards Acetonitrile (ACN), cyclohexane and ammonia solution (25\%) were purchased from VWR (Ismaning, Germany), methanol (MeOH) from Honeywell Riedel-de Haën (Seelze, Germany) and water from Th. Geyer (Renningen, Germany), all in analytical grade. Analytical standards for AOH, AME, ATXI, ATXII, STTXIII, ALTP, AOH-3-G, AOH-9-G and AME-3-G were isolated from fungal culture or synthesised at our chair as described previously (Gotthardt et al. 2020; Liu and Rychlik 2015; Scheibenzuber et al. 2020). TEN, ALT and TeA were bought from Merck (Darmstadt, Germany), and AOH-3-S and AME-3-S were isolated out of rice cultures of Alternaria alternata, as described in the following section. The labelled standards $\left[{ }^{2} \mathrm{H}_{4}\right]-\mathrm{AOH},\left[{ }^{2} \mathrm{H}_{4}\right]-\mathrm{AME}$ and $\left[{ }^{13} \mathrm{C}_{6},{ }^{15} \mathrm{~N}\right]-$ $\mathrm{TeA}$ were synthesised in our laboratory as reported previously (Asam et al. 2009, 2011).

Isolation of AOH-3-S and AME-3-S To obtain the modified toxins AOH-3-S and AME-3-S, rice was inoculated with $A$. alternata as described by Gotthardt et al. (2020). Briefly, $25 \mathrm{~g}$ of parboiled rice and $15 \mathrm{~mL}$ of water were put into polycarbonate Erlenmeyer flasks and autoclaved $\left(121^{\circ} \mathrm{C}\right.$, $20 \mathrm{~min}$ ). Spore suspensions of A. alternata isolated from potato leaves were diluted to $1.25 \cdot 10^{6}$ spores $/ \mathrm{mL}$ with a $0.5 \%$ Tween 20 solution, and $25 \mu \mathrm{L}$ was added to the rice in the flasks. Cultivation took place at $26{ }^{\circ} \mathrm{C}$ and $110 \mathrm{rpm}$ in a shaking water bath in the dark with exposition to artificial light for $30 \mathrm{~min}$ per day. After 7 days, rice cultures were thoroughly homogenised and extracted three times with $1 \mathrm{~L}$ of methanol/ethyl acetate $(1 / 1 ; \mathrm{v} / \mathrm{v})$ on a horizontal shaker (250 rpm) for $1 \mathrm{~h}$.

After decantation of the extracts and evaporation of solvents using a rotary evaporator $\left(30^{\circ} \mathrm{C}\right)$, the residue was dry loaded onto a silica column (125 g, Mesh70-230, pore size $60 \AA$ Å, particle size 63-200 $\mu \mathrm{m}$, Sigma-Aldrich, Steinheim, Germany), which was equilibrated with dichloromethane/ methanol (9/1, v/v) beforehand. For elution of analytes, a gradient using $200 \mathrm{~mL}$ of different dichloromethane/ methanol solutions $(9 / 1 ; 7 / 1 ; 3 / 1 ; 1 / 1 ; 1 / 3 ; 1 / 7 ; 0 / 1 ; \mathrm{v} / \mathrm{v})$ was applied, and fractions of $50 \mathrm{~mL}$ each were collected. All fractions were analysed by liquid chromatography with mass spectrometry in the full scan mode (LC-MS) using $\mathrm{H}_{2} \mathrm{O} / \mathrm{ACN}(1 / 1 ; \mathrm{v} / \mathrm{v})$ as mobile phase and a flow rate of $0.4 \mathrm{~mL} / \mathrm{min}$. Samples containing the desired analytes were combined, evaporated to dryness $\left(30^{\circ} \mathrm{C}\right)$ and dry loaded onto a second silica column for fractionation, using the same gradient and solvents as before. Again, all fractions containing AOH-3-S and AME-3-S were combined, evaporated to dryness $\left(30^{\circ} \mathrm{C}\right)$ and taken up in $10 \mathrm{~mL} \mathrm{H}_{2} \mathrm{O} /$ $\operatorname{ACN}(1 / 1 ; v / v)$.

For the separation of AOH-3-S and AME-3-S, a semipreparative HPLC system (LaChrom, D-7000, Merck, Germany, in cooperation with Hitachi Instruments Inc., San Jose, CA, USA) was used in combination with a ProPack C18 column $(150 \times 10.0 \mathrm{~mm}, \mathrm{~S}-5 \mu \mathrm{m}, 12 \mathrm{~nm}$, YMC, YMC Europe GmbH, Dienslaken, Germany). Solvent A was ammoniumformate ( $5 \mathrm{mM}$ in water), solvent $\mathrm{B}$ was $0.1 \%$ formic acid in acetonitrile, and the injection volume was $50 \mu \mathrm{L}$. The gradient was set as follows: $0-5 \min 20 \% \mathrm{~B}, 5-25 \mathrm{~min}$ 20 to $65 \%$ B, 25-26 $\min 65$ to $90 \%$ B, 26-39 $\min 90 \%$ B, $39-42 \min 90$ to $20 \%$ B and $42-50$ min $20 \%$ B. Software for data analysis was the HPLC system manager (LaChrom, Merck, Germany, in cooperation with Hitachi Instruments Inc., USA, version 4.1).

The individual peaks for AOH-3-S and AME-3-S were identified based on their molecular mass using LC-MS full scans and collected from repetitive runs. For further identification, the isolated peaks were measured with LC-MS/MS, and the resulting fragment ions and retention times were compared with reference compounds we obtained from Hannes Puntscher (University of Vienna). For quantitation, samples were prepared for quantitative proton nuclear resonance spectroscopy ( ${ }^{1} \mathrm{H}$-qNMR) and measured on a Bruker AVIII system (400 MHz, Bruker, Rheinstetten, Germany) as described in Scheibenzuber et al. (2020) using the ${ }^{1} \mathrm{H}$ signals of $\mathrm{AOH}$ for the quantitation of $\mathrm{AOH}-3-\mathrm{S}$, and the ${ }^{1} \mathrm{H}$ signals of AME for the quantitation of AME-3-S.

Preparation of stock solutions After their synthesis, isolation or purchase, all toxins were identified with ${ }^{1} \mathrm{H}$ NMR, LC-MS and LC-MS/MS measurements and quantified by ${ }^{1} \mathrm{H}$-qNMR using the same parameters as described in Frank et al. (2014). Stock solutions of every analyte were prepared in concentrations between 1 and $100 \mu \mathrm{g} / \mathrm{mL}$ in acetonitrile (ATXI, ATXII, TEN, ALTP, ALT, AOH-3-G, AOH-9-G, AME-3-G, STTXIII) or methanol (AOH, AME, TeA, AOH-3-S, AME-3-S). For method validation and sample preparation, the stock solutions were further diluted and checked for purity using LC-MS full scans and LC-MS/ MS. All standards were stored at $-18{ }^{\circ} \mathrm{C}$ in the dark, and concentrations of diluted standards were checked regularly by UV spectrophotometric measurements (Genesys, 10S, 
UV-Vis spectrophotometer, Thermo Fisher Scientific, Madison, WI, USA) using precision cells made out of quartz glass (1 cm layer thickness, Hellma $\mathrm{GmbH} \& \mathrm{Co}$. KG, Müllheim, Germany). Molar extinction coefficients were either obtained from literature (Cole et al. 2003; Fleck 2014; Visconti and Sibilia 1994; Scheibenzuber et al. 2020) or determined beforehand by identifying the UV absorption maximum via full scan and measuring three different dilutions in triplicate against the used solvent. The molar extinction coefficient $\varepsilon\left(\mathrm{L} \mathrm{mol}^{-1} \mathrm{~cm}^{-1}\right)$ was then calculated for each dilution using $\varepsilon=($ absorption $\cdot 1000) /$ (concentration $[\mathrm{mmol} / \mathrm{L}] \cdot 1[\mathrm{~cm}]$ ).

Although we initially developed the analytical method for 14 Alternaria mycotoxins, STTXIII was only available in low concentrations and showed a reduced stability in standard solutions, so this toxin was only included qualitatively in the final method.

Samples Fifty different beer samples were bought in various supermarkets and a local beer store in Freising, Germany, during March and April 2019. Out of the 50 samples, nineteen were lager beers, eleven Pilsner, six bock beers, four wheat beers, two export beers and three craft beers (imported) as well as five other international beers.

Sample preparation Beer samples were degassed for at least $15 \mathrm{~min}$ and stored at $-20{ }^{\circ} \mathrm{C}$ until further analysis. In triplicate, $5 \mathrm{~mL}$ of the degassed sample was measured into a 50-mL centrifuge tube and, for quantitation, spiked with $100 \mu \mathrm{L}$ of a $0.1-\mu \mathrm{g} / \mathrm{mL}$ standard solution of $\left[{ }^{13} \mathrm{C}_{6},{ }^{15} \mathrm{~N}\right]-\mathrm{Te} \mathrm{A}$, $100 \mu \mathrm{L}$ of a $0.1-\mu \mathrm{g} / \mathrm{mL}$ standard solution of $\left[{ }^{2} \mathrm{H}_{4}\right]-\mathrm{AOH}$ and $100 \mu \mathrm{L}$ of a $0.01-\mu \mathrm{g} / \mathrm{mL}$ standard solution of $\left[{ }^{2} \mathrm{H}_{4}\right]-\mathrm{AME}$. To minimise matrix effects, $2.5 \mathrm{~mL}$ of cyclohexane was added to the sample, followed by shaking and centrifugation at $3220 \times g$ and $4{ }^{\circ} \mathrm{C}$ for $5 \mathrm{~min}$. After removal of the cyclohexane phase, $15 \mathrm{~mL}$ of acetonitrile was added to the sample, which was then shaken vigorously to induce matrix precipitation. After centrifugation at $3220 \times g$ and $4{ }^{\circ} \mathrm{C}$ for another $5 \mathrm{~min}$, the supernatant containing the extracted toxins was transferred into a $50-\mathrm{mL}$ pear-shaped flask, while the precipitate was taken up in $10 \mathrm{~mL} \mathrm{ACN} / \mathrm{H}_{2} \mathrm{O}(84 / 16$, v/v) and extracted for $10 \mathrm{~min}$ on a horizontal shaker. After extraction, the samples were centrifuged again at $3220 \times g$ and $4{ }^{\circ} \mathrm{C}$ for $5 \mathrm{~min}$, and the supernatant was added to the first extract in the respective 50-mL pear-shape flask. Then, the solvent was removed using a rotary evaporator $\left(40{ }^{\circ} \mathrm{C}\right)$. For further clean-up, the residue was taken up in $12 \mathrm{~mL} \mathrm{H}_{2} \mathrm{O}$ (adjusted to $\mathrm{pH} 5.5$ with formic acid) and then transferred onto Discovery ${ }^{\circledR}$ DSC-18 cartridges, which were preconditioned with $6 \mathrm{~mL}$ methanol and $6 \mathrm{~mL} \mathrm{H}_{2} \mathrm{O}$ ( $\mathrm{pH} \mathrm{5.5)}$, beforehand. After two washing steps, one with $6 \mathrm{~mL} \mathrm{H}_{2} \mathrm{O}$ and one with $6 \mathrm{~mL} \mathrm{ACN} / \mathrm{H}_{2} \mathrm{O}$ $(15 / 85, \mathrm{v} / \mathrm{v})$, the toxins were eluted with $6 \mathrm{~mL} \mathrm{MeOH}$ and
$9 \mathrm{~mL} \mathrm{MeOH} / 25 \%$ ammonia solution $(98 / 2$, v/v). After rotary evaporation of the solvent, samples were taken up in $1 \mathrm{~mL}$ $\mathrm{ACN} / \mathrm{H}_{2} \mathrm{O}(3 / 7, \mathrm{v} / \mathrm{v})$, membrane filtered $(0.22 \mu \mathrm{m})$ and stored at $-18{ }^{\circ} \mathrm{C}$ until LC-MS/MS measurements.

Multi-mycotoxin analysis via LC-MS/MS Chromatographic separation was performed on a Shimadzu Nexera X2 UHPLC system (Shimadzu, Kyoto, Japan). Separation of all analytes except TeA was done on a Hyperclone BDS C18 column (150×3.2 mm, $3 \mu \mathrm{m}, 130 \AA$, Phenomenex, Aschaffenburg, Germany), and the binary gradient system was as follows: 0-2 $\min 10 \% \mathrm{~B}, 2-2.5 \mathrm{~min} 10$ to $18 \% \mathrm{~B}, 2.5-10.5 \mathrm{~min} 18 \%$ B, 10.5-14 min 18 to $40 \%$ B, 14-20 min 40\% B, 20-23 min 40 to $100 \% \mathrm{~B}, 23-25 \min 100 \% \mathrm{~B}, 25-27 \mathrm{~min} 100$ to $10 \%$ $\mathrm{B}$ and $27-32 \mathrm{~min} 10 \% \mathrm{~B}$ with a flow rate of $0.3 \mathrm{~mL} / \mathrm{min}$. Solvent A was water, solvent B acetonitrile. The column oven was tempered to $40{ }^{\circ} \mathrm{C}$, and the injection volume was $10 \mu \mathrm{L}$. For the analysis of TeA, a Gemini-NX C18 column (150×4.6 mm, $3 \mu \mathrm{m}, 110 \AA$, Phenomenex, Aschaffenburg, Germany) was used with $5 \mathrm{mM}$ ammonium formate (adjusted to $\mathrm{pH} 9$ with ammonia solution) as solvent $\mathrm{A}$ and methanol as solvent B, as published previously (Asam et al. 2013). Flow rate was set to $0.5 \mathrm{~mL} / \mathrm{min}$, and the oven temperature was $40{ }^{\circ} \mathrm{C}$. The binary gradient system was $0-3$ min $5 \% \mathrm{~B}$, $5-8 \min 5$ to $100 \% \mathrm{~B}, 8-10 \min 100 \% \mathrm{~B}, 10-13 \min 100$ to $5 \% \mathrm{~B}$ and $13-24$ min 5\% B. Both methods could be run in sequence as the system provided automated column switching and fourfold solvent selection for each pump.

The LC was interfaced with a Shimadzu 8050 triple quadrupole mass spectrometer (Shimadzu Corporation, Kyoto, Japan). All measurements were conducted in the negative electrospray ionisation (ESI) mode. The ion source parameters were set as follows: interface temperature $300{ }^{\circ} \mathrm{C}$, heat block temperature $400{ }^{\circ} \mathrm{C}$, desolvation temperature $250{ }^{\circ} \mathrm{C}$, interface voltage $4 \mathrm{kV}$, heating gas flow $10 \mathrm{~L} / \mathrm{min}$, drying gas flow $10 \mathrm{~L} / \mathrm{min}$, nebulizing gas flow $3 \mathrm{~L} / \mathrm{min}$, and collisioninduced dissociation gas pressure $270 \mathrm{kPa}$. MS/MS measurements were operated in the multiple reaction monitoring (MRM) mode. All MS parameters were optimised by direct injection of each standard solution $(0.01$ to $1 \mu \mathrm{g} / \mathrm{mL})$ into the ion source. The two most dominant mass transitions were included into the LC-MS/MS method with one serving as quantifier and one being used as qualifier for confirmation of peak identity. All final collision energies, voltages, fragment ions and retention times are listed in Table 1. Typical LC-MS/MS chromatograms are shown in Figs. 2 and 3.

For data acquisition and data analysis, the LabSolutions Software (Shimadzu, Kyoto, Japan) was used.

Calibration and quantitation To obtain response curves for all analytes with a corresponding stable isotope-labelled 
Table 1 List of fragment ions and retention times (Rt) of the analyzed toxins and their corresponding optimised collision energies (CE) and voltages

\begin{tabular}{|c|c|c|c|c|c|c|}
\hline Analyte & Rt (min) & Precursor ion $\mathrm{m} / \mathrm{z}$ & Product ion $\mathrm{m} / \mathrm{z}$ & $\begin{array}{l}\text { Q1 pre- } \\
\text { bias [V] }\end{array}$ & $\mathrm{CE}[\mathrm{V}]$ & $\begin{array}{l}\text { Q3 } \\
\text { pre-bias } \\
\text { [V] }\end{array}$ \\
\hline \multirow[t]{2}{*}{$\mathrm{AOH}$} & \multirow[t]{2}{*}{$18.63 \pm 0.02$} & \multirow[t]{2}{*}{256.90} & 213.15 & 18 & 23 & 20 \\
\hline & & & 212.10 & 48 & 29 & 38 \\
\hline \multirow[t]{2}{*}[{}^{2}\mathrm{H}_{4}]{$-\mathrm{AOH}$} & \multirow[t]{2}{*}{$18.60 \pm 0.03$} & \multirow[t]{2}{*}{260.90} & 217.15 & 18 & 23 & 20 \\
\hline & & & 216.10 & 48 & 29 & 38 \\
\hline \multirow[t]{2}{*}{ AME } & \multirow[t]{2}{*}{$24.24 \pm 0.01$} & \multirow[t]{2}{*}{271.10} & 256.10 & 20 & 23 & 24 \\
\hline & & & 255.10 & 20 & 31 & 24 \\
\hline \multirow[t]{2}{*}[{}^{2}\mathrm{H}_{4}]{$-\mathrm{AME}$} & \multirow[t]{2}{*}{$24.22 \pm 0.01$} & \multirow[t]{2}{*}{275.10} & 260.10 & 20 & 23 & 24 \\
\hline & & & 259.10 & 20 & 31 & 24 \\
\hline \multirow[t]{2}{*}{ ALT } & \multirow[t]{2}{*}{$16.79 \pm 0.01$} & \multirow[t]{2}{*}{291.10} & 203.20 & 30 & 35 & 18 \\
\hline & & & 248.15 & 24 & 27 & 14 \\
\hline \multirow[t]{2}{*}{ ALTP } & \multirow[t]{2}{*}{$18.60 \pm 0.03$} & \multirow[t]{2}{*}{349.10} & 261.20 & 26 & 30 & 26 \\
\hline & & & 303.20 & 26 & 22 & 18 \\
\hline \multirow[t]{2}{*}{ ATX I } & \multirow[t]{2}{*}{$18.23 \pm 0.02$} & \multirow[t]{2}{*}{351.10} & 315.15 & 26 & 18 & 18 \\
\hline & & & 297.15 & 26 & 28 & 18 \\
\hline \multirow[t]{2}{*}{ ATX II } & \multirow[t]{2}{*}{$22.87 \pm 0.03$} & \multirow[t]{2}{*}{349.10} & 313.20 & 16 & 18 & 20 \\
\hline & & & 330.15 & 26 & 26 & 18 \\
\hline \multirow[t]{2}{*}{ STTX III } & \multirow[t]{2}{*}{$23.38 \pm 0.03$} & \multirow[t]{2}{*}{347.10} & 329.15 & 12 & 20 & 20 \\
\hline & & & 301.10 & 16 & 35 & 30 \\
\hline \multirow[t]{2}{*}{ TEN } & $19.43 \pm 0.01$ & 413.40 & 141.05 & 14 & 23 & 12 \\
\hline & & & 214.25 & 14 & 26 & 20 \\
\hline $\mathrm{TeA}$ & $8.16 \pm 0.01$ & 196.30 & 139.00 & 14 & 22 & 11 \\
\hline & & & 112.05 & 22 & 26 & 20 \\
\hline$\left[{ }^{13} \mathrm{C}_{6},{ }^{15} \mathrm{~N}\right]-\mathrm{Te} A$ & $18.16 \pm 0.01$ & 203.25 & 142.00 & 14 & 22 & 11 \\
\hline & & & 113.05 & 22 & 26 & 20 \\
\hline $\mathrm{AOH}-3-\mathrm{S}$ & $6.05 \pm 0.21$ & 337.00 & 257.15 & 24 & 26 & 26 \\
\hline & & & 213.15 & 24 & 39 & 20 \\
\hline AOH-3-G & $14.95 \pm 0.03$ & 419.10 & 256.15 & 30 & 33 & 26 \\
\hline & & & 228.20 & 30 & 45 & 12 \\
\hline AOH-9-G & $14.22 \pm 0.04$ & 419.10 & 283.30 & 12 & 30 & 32 \\
\hline & & & 256.15 & 18 & 35 & 28 \\
\hline AME-3-S & $10.98 \pm 0.2$ & 351.20 & 271.20 & 12 & 23 & 26 \\
\hline & & & 256.15 & 12 & 35 & 24 \\
\hline AME-3-G & $17.38 \pm 0.02$ & 433.00 & 270.20 & 16 & 33 & 18 \\
\hline & & & 227.10 & 12 & 54 & 20 \\
\hline
\end{tabular}

standard, i.e., $\mathrm{AOH}, \mathrm{AME}$, and TeA, constant amounts of the labelled standards $(\mathrm{S})\left[{ }^{2} \mathrm{H}_{4}\right]-\mathrm{AOH},\left[{ }^{2} \mathrm{H}_{4}\right]-\mathrm{AME}$, and $\left[{ }^{13} \mathrm{C}_{6},{ }^{15} \mathrm{~N}\right]-\mathrm{Te} A$ were mixed with different amounts of the corresponding analytes (A) $\mathrm{AOH}, \mathrm{AME}$, and TeA in molar ratios between 0.01 and $100(1: 100,1: 50,1: 20,1: 10,1: 5$, $1: 2,1: 1,2: 1,5: 1,10: 1,50: 1$, and 100:1). After LC-MS/ MS measurements, response curves were obtained by plotting peak area ratios $[\mathrm{A}(\mathrm{A}) / \mathrm{A}(\mathrm{S})]$ against molar ratios $[\mathrm{n}(\mathrm{A}) / \mathrm{n}(\mathrm{S})]$. Response functions were calculated by linear regression.

For analytes without a stable isotope-labelled standard, matrix-matched calibration was performed using a beer without the analytes of interest as a blank matrix. To obtain matrix-matched calibration curves, 8 to 10 matrix calibration points were prepared, ranging from 0.93 to $100 \mu \mathrm{g} / \mathrm{L}$ (TEN), from 0.62 to $10 \mu \mathrm{g} / \mathrm{L}$ (ATXI), from 1.75 to $10 \mu \mathrm{g} / \mathrm{L}$ (ATXII), from 2.84 to $10 \mu \mathrm{g} / \mathrm{L}$ (ALTP), from 16.1 to $100 \mu \mathrm{g} / \mathrm{L}$ (ALT), from 1.35 to $14 \mu \mathrm{g} / \mathrm{L}$ (AOH-3-G), from 1.3 to $14 \mu \mathrm{g} / \mathrm{L}$ (AOH-9-G), from 2.35 to $13 \mu \mathrm{g} / \mathrm{L}$ (AME-3-G), from 1.7 to $20 \mu \mathrm{g} / \mathrm{L}$ (AOH-3-S) and from 3.4 to $20 \mu \mathrm{g} / \mathrm{L}$ (AME-3-S). After LC-MS/MS measurements, matrix-matched calibration curves were obtained by plotting peak areas $[\mathrm{A}(\mathrm{A})]$ against concentration of the analytes $[\mathrm{c}(\mathrm{A})]$ and performing linear regression.

Linearity was confirmed for all analytes by applying Mandel's fitting test (Mandel 1964). 

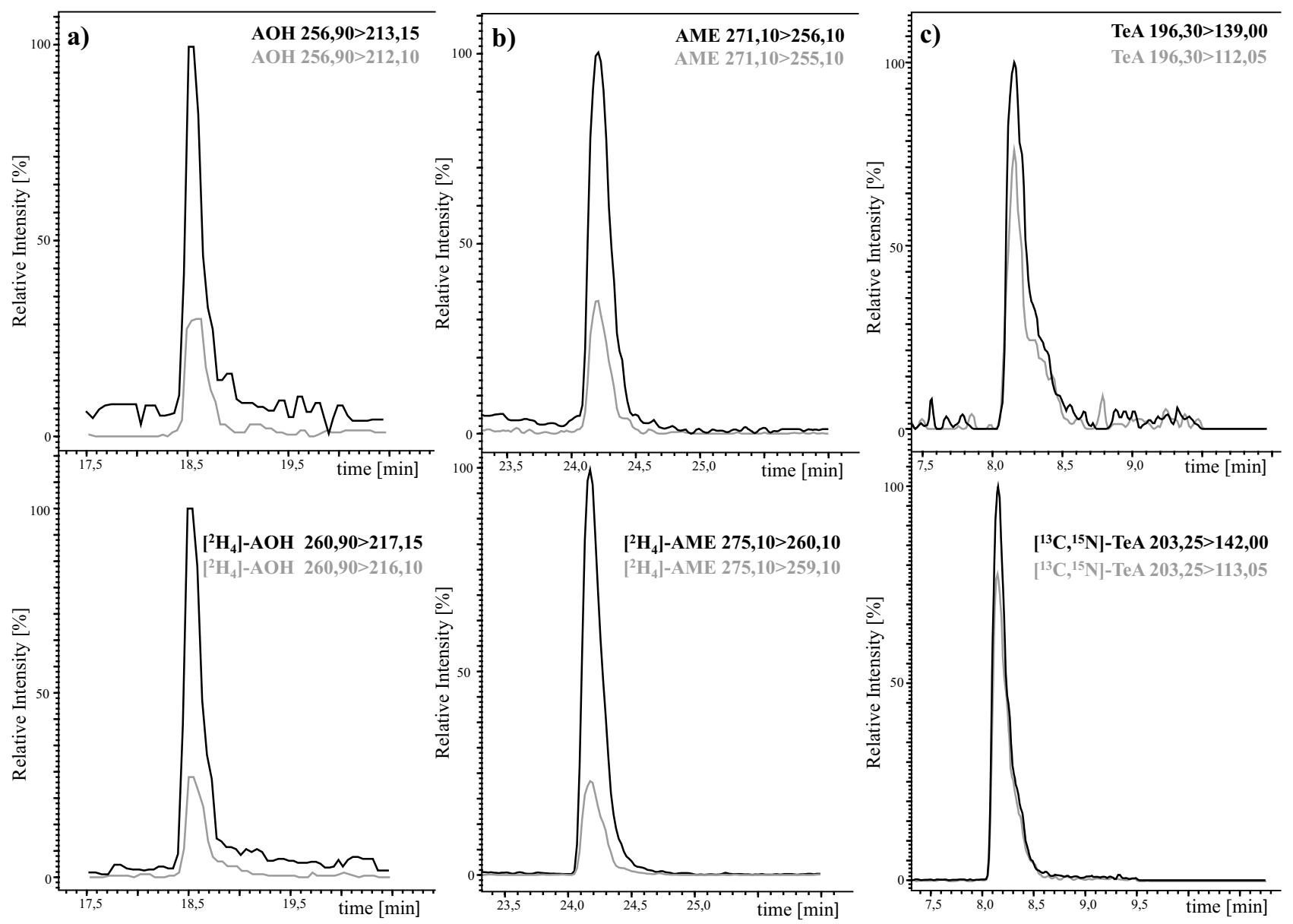

Fig. 2 LC-MS/MS chromatograms of AOH (a), AME (b) and TeA (c), and their stable isotope-labelled analogues. The respective transition used for quantitation is shown in black and the transition used for confirmation in grey

The mycotoxin content in the beer samples was calculated either by the respective response curve or by matrixmatched calibration. To ensure correct values, two matrix calibration points were prepared with each sample work-up to compensate for intensity variability of the LC-MS/MS measurements.

Method validation LODs and LOQs. The limits of detection (LODs) and limits of quantitation (LOQs) were determined according to Vogelgesang and Hädrich (1998). The blank beer matrix was spiked at four different concentration levels with the unlabelled analytes $\mathrm{AOH}(0.4,1.2,2.6$ and $4 \mu \mathrm{g} / \mathrm{L})$, AME $(0.05,0.15,0.33$ and $0.5 \mu \mathrm{g} / \mathrm{L}), \mathrm{TeA}(0.5,1.5,3.25$ and $5 \mu \mathrm{g} / \mathrm{L})$, TEN $(0.2,0.6,1.3$ and $2 \mu \mathrm{g} / \mathrm{L})$, ATXI $(0.3$, $0.9,1.95$ and $3 \mu \mathrm{g} / \mathrm{L})$, ATXII $(0.2,1,2.5$ and $4 \mu \mathrm{g} / \mathrm{L})$, ALTP $(0.6,1.8,3.9$ and $6 \mu \mathrm{g} / \mathrm{L})$, ALT $(8,24,52$ and $80 \mu \mathrm{g} / \mathrm{L})$, AOH-3-G $(0.3,1.5,3$ and $4.5 \mu \mathrm{g} / \mathrm{L})$, AOH-9-G $(0.3,1.5$, 3 and $4.5 \mu \mathrm{g} / \mathrm{L})$, AME-3-G (1.5, 5, 7.5 and $9 \mu \mathrm{g} / \mathrm{L})$, AOH$3-\mathrm{S}(0.2,1.5,3$ and $5 \mu \mathrm{g} / \mathrm{L})$ and AME-3-S (5, 7.5, 10 and $15 \mu \mathrm{g} / \mathrm{L})$. After adding the isotope-labelled standards, the spiked blank samples were subjected sample preparation as described above and measured using LC-MS/MS. Every spiking level was prepared in triplicate.
Precision A beer sample naturally contaminated with TeA was spiked with the other toxins $(0.8 \mu \mathrm{g} / \mathrm{L} \mathrm{AOH}, 0.33 \mu \mathrm{g} / \mathrm{L}$ AME, $0.5 \mu \mathrm{g} / \mathrm{L}$ TEN, $0.9 \mu \mathrm{g} / \mathrm{L}$ ATXI, $4 \mu \mathrm{g} / \mathrm{L}$ ATXII, $1.8 \mu \mathrm{g} / \mathrm{L}$ ALTP, $24 \mu \mathrm{g} / \mathrm{L}$ ALT, $3 \mu \mathrm{g} / \mathrm{L}$ AOH-3-G, $3 \mu \mathrm{g} / \mathrm{L}$ AOH-9-G, $4 \mu \mathrm{g} / \mathrm{L}$ AME-3-G, $5 \mu \mathrm{g} / \mathrm{L}$ AOH-3-S and $7.5 \mu \mathrm{g} / \mathrm{L}$ AME-3-S) and used for intra-day $(n=3)$ and inter-day $(n=9$, triplicate measurement every week within 3 weeks) precision measurements.

Recovery Mycotoxin-free beer samples were spiked in triplicate with three different concentrations of $\mathrm{AOH}$ $(1.2,2.6$ and $4 \mu \mathrm{g} / \mathrm{L})$, AME $(0.15,0.33$ and $0.5 \mu \mathrm{g} / \mathrm{L})$, TeA $(1.5,3.25$ and $5 \mu \mathrm{g} / \mathrm{L})$, TEN $(1.3,2$ and $2.5 \mu \mathrm{g} / \mathrm{L})$, ATXI $(0.90,1.95$ and $3 \mu \mathrm{g} / \mathrm{L})$, ATXII $(2.5,4$ and $5 \mu \mathrm{g} / \mathrm{L})$, ALTP $(3.9,4.5$ and $6 \mu \mathrm{g} / \mathrm{L})$, ALT $(24,52$ and $80 \mu \mathrm{g} / \mathrm{L})$, AOH-3-G (1.5, 3 and $4 \mu \mathrm{g} / \mathrm{L})$, AOH-9-G $(1.5,3$ and $4.5 \mu \mathrm{g} / \mathrm{L})$, AME-3-G (5, 7.5 and $9 \mu \mathrm{g} / \mathrm{L}), \mathrm{AOH}-3-\mathrm{S}(3,5$ and $7 \mu \mathrm{g} / \mathrm{L})$ and AME-3-S (5, 7.5 and $10 \mu \mathrm{g} / \mathrm{L})$ and analyzed after sample preparation. To obtain the recovery values, the ratio of detected and spiked contents was calculated. 


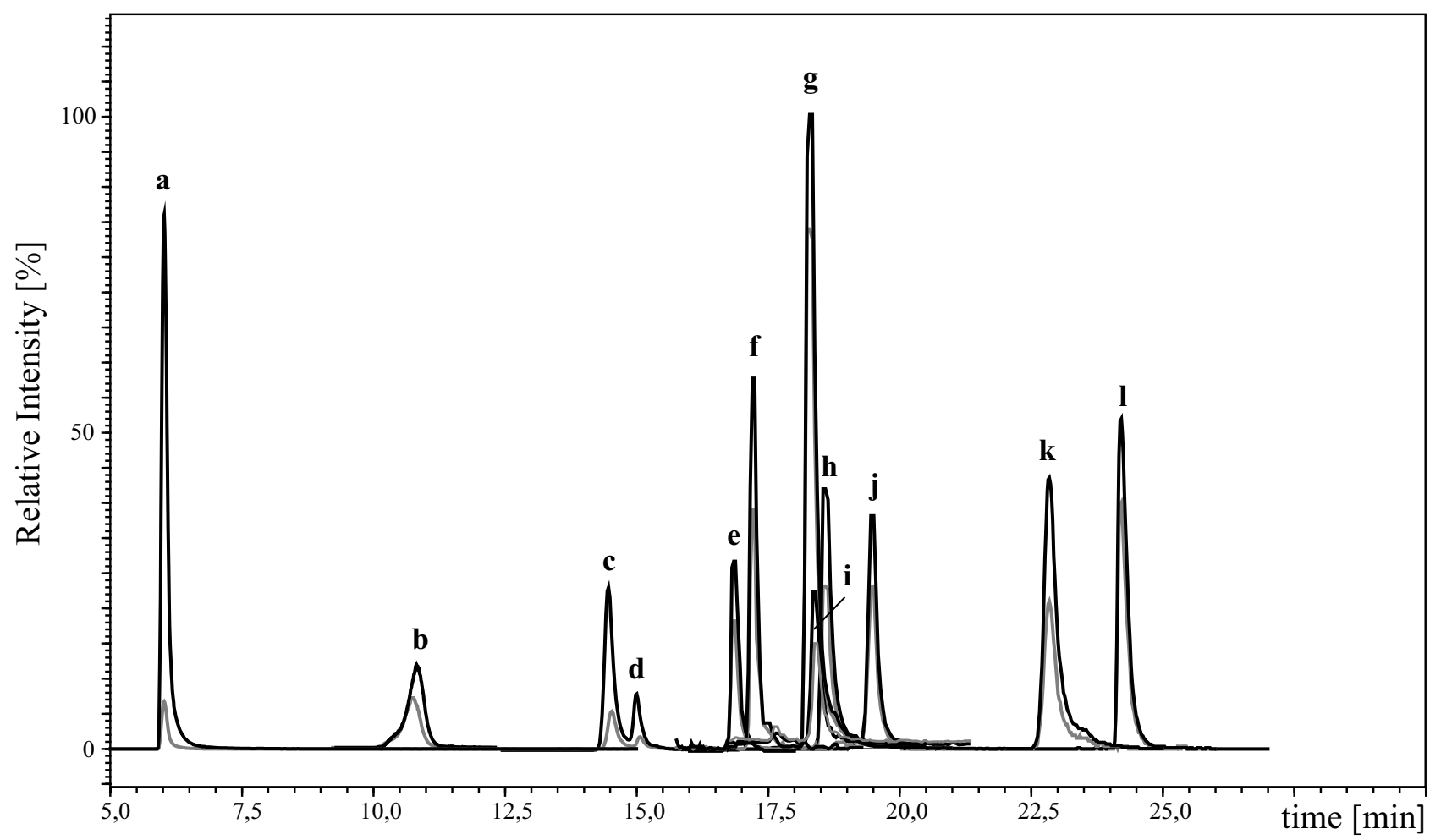

Fig. 3 LC-MS/MS chromatogram of the 12 Alternaria mycotoxins AOH-3-S (a), AME-3-S (b), AOH-9-G (c), AOH-3-G (d), ALT (e), AME3-G (f), ATXI (g), AOH (h), ALTP (i), TEN (j), ATXII (k) and AME (l). The chromatogram for TeA is included in Fig. 2

\section{Results and discussion}

Determination of UV molar extinction coefficients Molar extinction coefficients were determined for ALT and TEN in acetonitrile and for AOH-3-S, AME-3-S and TeA in methanol. The obtained values were used to regularly check standard concentrations of the reference compounds and to further characterise the modified toxins AOH-3-S and AME$3-\mathrm{S}$. The results are listed in Table 2.

Sample preparation First, experiments showed that a dilute and shoot method did not deliver acceptable results in terms of sensitivity for this study. Consequently, different extraction and clean-up techniques were tested with spiked beer samples.

Matrix precipitation was a step commonly applied in beer analysis in literature, so we tested different volumes of ACN to find the most effective and economic method (Habler et al. 2017; Zachariasova et al. 2010). However, HPLC-UV studies revealed the presence of many matrix peaks, even after addition of high amounts of organic solvent, which required a further clean-up step using solidphase extraction (SPE). Furthermore, AME tended to be bound by the precipitate, which could be solved by an
Table 2 Absorption maxima and molar extinction coefficients of TEN, ALT, TeA, AOH-3-S and AME-3-S. Molar extinction coefficient values were rounded and are given as the mean value of three concentration levels measured three times in triplicate

\begin{tabular}{lllll}
\hline Analyte & $\begin{array}{l}\text { Absorption maxima } \\
(\mathrm{nm})\end{array}$ & $\begin{array}{l}\text { Concentration levels } \\
(\mu \mathrm{g} / \mathrm{mL})\end{array}$ & Solvent & $\begin{array}{l}\text { Molar extinction coef- } \\
\text { ficient } \varepsilon\left(\mathrm{L} \mathrm{mol}^{-1} \mathrm{~cm}^{-1}\right)\end{array}$ \\
\hline TEN & 279 & $5.0 / 10.0 / 15.0$ & $\mathrm{ACN}$ & $\varepsilon_{279 \mathrm{~nm}}=20,250 \pm 1500$ \\
& 210 & $1.0 / 5.0 / 10.0$ & $\mathrm{MeOH}$ & $\varepsilon_{242 \mathrm{~nm}}=28,700 \pm 770$ \\
ALT & 242 & $5.0 / 10.0 / 20.0$ & $\mathrm{MeOH}$ & $\varepsilon_{278 \mathrm{~nm}}=13,900 \pm 490$ \\
TeA & 279 & $1.0 / 2.5 / 5.0$ & $\mathrm{MeOH}$ & $\varepsilon_{251 \mathrm{~nm}}=48,300 \pm 1800$ \\
AOH-3-S & 278 & $1.0 / 2.5 / 5.0$ & $\mathrm{MeOH}$ & $\varepsilon_{253 \mathrm{~nm}}=55,400 \pm 1500$ \\
& 251 & & & \\
\hline
\end{tabular}


additional extraction step of the residue. Unfortunately, direct use of the untreated beer for the SPE clean-up delivered good results for all toxins except the two very polar modified metabolites AOH-3-S and AME-3-S. These two analytes apparently did not bind to the solid phase either due to the alcohol content in the sample or other unfavorable interactions between analyte and sorbent material.

After further optimisation of the matrix precipitation and the SPE conditions, the matrix was clearly reduced when measured with HPLC-UV. However, when measured with LC-MS/MS, matrix effects were still observed, especially during the elution of the polar compounds $\mathrm{AOH}-$ 3-S, AME-3-S, AOH-9-G and AOH-3-G, which negatively affected the LODs and LOQs. As those modified forms were never analyzed in beer before, we aimed to improve the analysis by testing an additional liquid-liquid extraction step. For this purpose, extraction with cyclohexane delivered the best results, even in small volumes. During this step, we observed a transition of low amounts of AME into the cyclohexane phase, which was decided to be negligible due to compensation by the SIDA used for this compound.

After combining all these steps, we obtained a sample preparation method that was highly efficient for the analysis of both free and modified Alternaria mycotoxins in beer samples and delivered reproducible values.

Calibration and quantitation Response functions were obtained for $\mathrm{AOH}, \mathrm{AME}$ and $\mathrm{TeA}$ with their corresponding labelled analogues using linear regression. Linearity was confirmed by Mandel's fitting test (Mandel 1964) between molar ratios $\mathrm{n}(\mathrm{A}) / \mathrm{n}(\mathrm{S})$ of $0.01-100$ for all three analytes.
For the toxins without a labelled standard, matrix-calibration curves were generated by spiking a toxin-free beer sample in a concentration range starting from the LOQ of the respective toxin to at least ten times the LOQ. The linear range of the calibration was checked with Mandel's fitting test (Mandel 1964) and the range reduced if necessary. Hence, linearity was confirmed from 0.93 to $100 \mu \mathrm{g} / \mathrm{L}$ for TEN, from 0.62 to $10 \mu \mathrm{g} / \mathrm{L}$ for ATXI, from 1.75 to $10 \mu \mathrm{g} / \mathrm{L}$ for ATXII, from 2.84 to $10 \mu \mathrm{g} / \mathrm{L}$ for ALTP, from 16.1 to $100 \mu \mathrm{g} / \mathrm{L}$ for ALT, from 1.35 to $14 \mu \mathrm{g} / \mathrm{L}$ for $\mathrm{AOH}-3-\mathrm{G}$, from 1.3 to $14 \mu \mathrm{g} / \mathrm{L}$ for $\mathrm{AOH}-9-\mathrm{G}$, from 2.35 to $13 \mu \mathrm{g} / \mathrm{L}$ for AME-3-G, from 1.7 to $20 \mu \mathrm{g} / \mathrm{L}$ for AOH-3-S and from 3.4 to $20 \mu \mathrm{g} / \mathrm{L}$ for AME-3-S.

\section{Method validation}

The limits of detection (LODs) and limits of quantification (LOQs) were determined for every analyte in a toxin-free beer matrix as described by Vogelgesang and Hädrich (1998). The obtained LODs ranged from $0.03 \mu \mathrm{g} / \mathrm{L}$ (AME) to $5.48 \mu \mathrm{g} / \mathrm{L}$ (ALT), the LOQ values were between $0.09 \mu \mathrm{g} / \mathrm{L}$ (AME) and $16.24 \mu \mathrm{g} / \mathrm{L}$ (ALT). Detailed values for each toxin are listed in Table 3. Generally, the LODs and LOQs were low for all analytes determined by SIDA, i.e. AOH, AME and TeA. However, the values for the other toxins determined by matrix-matched calibration were also in a good range, which showed the good applicability of a matrix-matched calibration when stable isotope-labelled standards are not available. The only exception was ALT that has already been proven in literature to be most sensitively determined in the positive ESI mode. As this study used
Table 3 Limits of detection (LODs), limits of quantitation (LOQs), recoveries, interinjection precisions $(n=5)$, intra-day precisions $(n=3)$ and inter-day precisions $(n=9)$ for 13 Alternaria toxins in beer

\begin{tabular}{|c|c|c|c|c|c|c|c|c|}
\hline \multirow[t]{2}{*}{ Analyte } & \multirow[t]{2}{*}{ LOD $(\mu \mathrm{g} / \mathrm{L})$} & \multirow[t]{2}{*}{ LOQ $(\mu \mathrm{g} / \mathrm{L})$} & \multicolumn{3}{|c|}{ Recovery (\%) } & \multicolumn{3}{|c|}{ RSD (\%) } \\
\hline & & & Level 1 & Level 2 & Level 3 & $\begin{array}{l}\text { Inter- } \\
\text { injection }\end{array}$ & Intra-day & Inter-day \\
\hline $\mathrm{AOH}$ & 0.15 & 0.52 & $95 \pm 4$ & $95 \pm 1$ & $92 \pm 3$ & 2 & 5 & 5 \\
\hline AME & 0.03 & 0.09 & $102 \pm 1$ & $100 \pm 5$ & $96 \pm 3$ & 2 & 2 & 3 \\
\hline $\mathrm{TeA}$ & 0.15 & 0.46 & $87 \pm 2$ & $91 \pm 1$ & $86 \pm 4$ & 3 & 4 & 4 \\
\hline TEN & 0.24 & 0.93 & $92 \pm 5$ & $105 \pm 6$ & $105 \pm 8$ & 3 & 7 & 8 \\
\hline ATX I & 0.2 & 0.62 & $114 \pm 4$ & $111 \pm 6$ & $107 \pm 7$ & 4 & 6 & 9 \\
\hline ATX II & 0.43 & 1.73 & $103 \pm 7$ & $98 \pm 5$ & $87 \pm 2$ & 5 & 5 & 8 \\
\hline ALTP & 0.68 & 2.84 & $99 \pm 3$ & $110 \pm 4$ & $101 \pm 7$ & 4 & 8 & 8 \\
\hline ALT & 5.48 & 16.24 & $107 \pm 14$ & $104 \pm 8$ & $106 \pm 3$ & 2 & 6 & 9 \\
\hline $\mathrm{AOH}-3-\mathrm{G}$ & 0.45 & 1.32 & $72 \pm 3$ & $94 \pm 8$ & $104 \pm 8$ & 2 & 5 & 9 \\
\hline $\mathrm{AOH}-9-\mathrm{G}$ & 0.32 & 1.28 & $101 \pm 3$ & $98 \pm 10$ & $101 \pm 3$ & 3 & 6 & 7 \\
\hline AME-3-G & 0.72 & 2.32 & $113 \pm 9$ & $101 \pm 2$ & $103 \pm 2$ & 3 & 8 & 10 \\
\hline $\mathrm{AOH}-3-\mathrm{S}$ & 0.46 & 1.67 & $87 \pm 7$ & $84 \pm 9$ & $88 \pm 5$ & 4 & 5 & 8 \\
\hline AME-3-S & 0.78 & 3.42 & $86 \pm 1$ & $96 \pm 3$ & $94 \pm 5$ & 4 & 9 & 10 \\
\hline
\end{tabular}


negative ESI mode, higher LOD and LOQ values had to be accepted for ALT in this multitoxin approach, because all other analytes were more sensitive in the negative mode than in the positive mode. However, the obtained values for ALT in this study are comparable with other methods using negative ESI mode (Walravens et al. 2014; Zwickel et al. 2016), but a measurement in the positive ESI mode or applying the polarity switching technique should be the methods of choice when focusing on ALT in the future (Prelle et al. 2013).

The recovery of each analyte was determined by spiking blank beer matrix samples at three different concentration levels. According to theory, the spiking levels should comply with mycotoxin concentrations that are to be expected in naturally contaminated beer. However, as most of the analyzed 13 Alternaria toxins have never been found or analyzed in beer before, low or no toxin concentrations were expected. Consequently, the three spiking levels for recovery determination were chosen close to the LOQ. In this range, recoveries ranged from 72 to $113 \%$ (Table 3), which laid within the acceptable range of 70 to $120 \%$ (Vogelgesang and Hädrich 1998).

The precision of the developed method was calculated for each analyte as the relative standard deviation (RSD) of repeated measurements. Results are given in Table 3. To obtain the inter-injection precision, one spiked beer sample was repetitively measured $(n=5)$ with LC-MS/MS. Interinjection RSD values ranged from 2 to $5 \%$, which showed the stability of the used system. For the other RSD values, one sample was prepared in triplicate (intra-day precision) and again in triplicate every week within 3 weeks (inter-day precision). Intra-day precisions were 2 to $9 \%$ and inter-day precisions lay between 3 and $10 \%$, which demonstrated good precision of the developed method.

Screening of 13 free and modified Alternaria toxins All 50 beer samples were prepared according to the sample workup procedure described above and then screened for all Alternaria toxins except TeA using the LC-MS/MS multimethod. Measurements revealed that no free and modified toxins were present in any sample above their limit of detection, which was quite surprising in terms of $\mathrm{AOH}$, as this toxin has been found in many beer samples before (Bauer et al. 2016; Prelle et al. 2013). All other analyzed toxins have also been found only rarely or not at all in previous studies (Prelle et al. 2013). Thus, it might be concluded that they were either not present in the raw material or their concentration decreased during the brewing process until below their limit of detection. However, this question must be addressed in further studies as data on Alternaria toxins in beer are only rarely available, especially for ALTP, ATXI, ATXII, ALT and TEN. As the focus of many mycotoxin multi-methods in cereal products including beer is not on
Alternaria but on Fusarium toxins, mostly only the most prominent toxins $\mathrm{AOH}, \mathrm{AME}$ and $\mathrm{TeA}$ were included into those methods, and data about other Alternaria toxins are missing. Also, modified forms of AOH and AME have never been analyzed before in this matrix.

In an Italian study, Prelle et al. (2013) found AOH in several beer samples from 2012 in a concentration range of 6.04-23.2 $\mu \mathrm{g} / \mathrm{L}$ using LC-MS/MS with atmospheric pressure chemical ionisation (APCI), while Bauer et al. (2016) found lower amounts of $\mathrm{AOH}$ with concentrations ranging between 0.23 and $1.6 \mu \mathrm{g} / \mathrm{L}$ using enzyme-linked immunosorbent assay (ELISA). The difference between our results and the high $\mathrm{AOH}$ concentrations from Italy (Prelle et al. 2013) could partly be a result of the German purity law, which is obligatory for all beers produced in Germany and only allows few ingredients for beer production. Consequently, toxin levels can be higher when other ingredients, e.g. rice or maize, are used for the brewing process, which might elevate the total mycotoxin content in the final product. However, some foreign beers were also analyzed in this study and no $\mathrm{AOH}$ could be detected in those samples either.

Although Bauer et al. (2016) only found low amounts of $\mathrm{AOH}$, they could detect it in every sample with their ELISA test with a LOD of $0.18 \mu \mathrm{g} / \mathrm{L}$. Surprisingly, in our study, no beer was contaminated with $\mathrm{AOH}$ above the LOD of $0.15 \mu \mathrm{g} / \mathrm{L}$. However, the spring and summer of 2018 was generally quite dry in Germany, which assumingly did not promote Alternaria spp. growth like in the years before. Therefore, the mycotoxin contamination of the 2018 harvest should have been relatively low, which could explain the divergent results from our study compared with the other studies. Also, Puangkham et al. (2017) analyzed 100 beer samples from Thailand and obtained similar results compared with our study, which again suggests that the mycotoxin concentration in beer can vary between different countries and different harvest or production years.

Quantitation of TeA using stable-isotope dilution assay As expected, TeA was found in almost every sample, i.e. in 48 out of 50 beers, and in comparable amounts with a previous study (Siegel et al. 2010). Only two beers from Ireland were completely free of Alternaria mycotoxins, and all others contained TeA in concentrations between $0.69 \pm 0.06 \mu \mathrm{g} / \mathrm{L}$ and $16.5 \pm 2.2 \mu \mathrm{g} / \mathrm{L}$. All beer samples were sorted into groups according to their beer type, and the average group mean value was calculated. An overview of the obtained results is shown in Table 4, and a detailed list of TeA concentrations can be found in the Supplementary Information.

In our study, more samples were tested positive for TeA than in the study by Siegel et al. (2010), in which less than 
Table 4 Summary of TeA concentrations in 50 beer samples, sorted into groups according to their beer type. Average concentrations of each sample were determined as mean value of three replicates and double injections

\begin{tabular}{llllc}
\hline Group & $\begin{array}{l}\text { Sample } \\
\text { number }\end{array}$ & $\begin{array}{l}\text { Samples } \\
\text { containing } \\
\text { TeA }\end{array}$ & $\begin{array}{l}\text { Average TeA } \\
\text { concentration } \\
(\mu \mathrm{g} / \mathrm{L})\end{array}$ & $\begin{array}{l}\text { Highest TeA } \\
\text { concentration } \\
(\mu \mathrm{g} / \mathrm{L})\end{array}$ \\
\hline Pilsener beer & 11 & 11 & $4.28 \pm 3.00$ & $8.87 \pm 0.43$ \\
Lager beer & 19 & 19 & $5.82 \pm 3.18$ & $12.21 \pm 0.38$ \\
Wheat beer & 4 & 4 & $5.72 \pm 2.62$ & $8.74 \pm 0.75$ \\
Bock beer & 6 & 6 & $11.35 \pm 3.91$ & $16.5 \pm 2.2$ \\
Craft beer & 3 & 3 & $3.14 \pm 1.24$ & $3.88 \pm 0.29$ \\
Export beer & 2 & 2 & $4.85 \pm 3.21$ & $7.12 \pm 0.28$ \\
International & 5 & 3 & $6.34 \pm 7.56$ & $3.40 \pm 0.25$ \\
\hline
\end{tabular}

$40 \%$ of the samples contained TeA. This could be due to the different LOD and LOQ values and different analytical approaches: by using a derivatisation step for the analysis of TeA, Siegel et al. (2010) obtained a LOD of $2 \mu \mathrm{g} / \mathrm{L}$ and a LOQ of $8 \mu \mathrm{g} / \mathrm{L}$, which is higher than that in our study. Although derivatisation normally leads to a more sensitive method, we could improve our LOD and LOQ values by applying SIDA and using an almost tenfold sample volume. Therefore, we could also detect low TeA concentrations in samples, which would probably have been tested negative in Siegel et al. (2010).

The standard deviation in the group mean values (Table 4) shows that the variation within the groups is high, which indicates that the TeA content might depend more on the contamination of the raw material than on the beer type. Siegel et al. (2010) proposed that the TeA content is higher in bock beers due to the higher wort content in this beer type. At first sight, our study seems to confirm this assumption, as both the sample with the highest content of TeA was a bock beer and also the mean concentration of TeA was highest in this type of beers. However, this finding has to be interpreted carefully, as we observed similar high concentrations of TeA in some samples of lager beers, and the dataset for bock beers was much smaller than for larger beers. From a theoretical point of view, when a lager and a bock beer are brewed from the same malt as starting material, it is most likely that the bock beer has a higher TeA concentration due to the higher wort content. However, as the toxin content in barley as well as in malt is highly variable, this assumption cannot be verified when different starting materials are used. For that reason, we propose that $\mathrm{TeA}$ concentration in beer is mainly dependent on the contamination of raw material and only less dependent on the wort content.

In conclusion, $\mathrm{Te} \mathrm{A}$ was found to be the only relevant Alternaria toxin in beer in this study. However, toxin concentrations were quite low with a maximum value of $16.5 \pm 2.2 \mu \mathrm{g} / \mathrm{L}$, which was found in a bock beer. Therefore, the TTC value for TeA, i.e. $1500 \mathrm{ng} / \mathrm{kg}$ body weight per day, will not be reached by drinking reasonable amounts of beer. When an adult person with $70 \mathrm{~kg}$ body weight is consuming $1 \mathrm{~L}$ per day of the highest contaminated beer in this study, this will yield a daily intake of $235 \mathrm{ng} / \mathrm{kg}$ body weight per day. Nevertheless, in combination with other foods contaminated with TeA, beer consumption could considerably contribute to the total intake of TeA.

Supplementary Information The online version contains supplementary material available at https://doi.org/10.1007/s12550-021-00424-0.

Acknowledgements We would like to thank Franziska Hesse and Anna Reitsam for their assistance with sample work up.

Author contribution Method development, method validation and sample analysis were performed by Sophie Scheibenzuber and Fabian Dick. The first draft of the manuscript was written by Sophie Scheibenzuber and was revised by Stefan Asam and Michael Rychlik. All the authors read and approved the final manuscript.

Funding Open Access funding enabled and organized by Projekt DEAL. This research was funded by the Forschungskreis der Ernährungsindustrie e.V. (FEI) and the Industrielle Gemeinschaftsforschung (IGF) (Project No: 19766N), the German Federal Ministry of Economic Affairs and Energy and the Wissenschaftliche Station für Brauerei in München.

Data availability The datasets generated during and analysed during the current study are available from the corresponding author on reasonable request.

\section{Declarations}

Conflict of interest The authors declare that they have no conflict of interest.

Open Access This article is licensed under a Creative Commons Attribution 4.0 International License, which permits use, sharing, adaptation, distribution and reproduction in any medium or format, as long as you give appropriate credit to the original author(s) and the source, provide a link to the Creative Commons licence, and indicate if changes were made. The images or other third party material in this article are included in the article's Creative Commons licence, unless indicated otherwise in a credit line to the material. If material is not included in the article's Creative Commons licence and your intended use is not permitted by statutory regulation or exceeds the permitted use, you will need to obtain permission directly from the copyright holder. To view a copy of this licence, visit http://creativecommons.org/licenses/by/4.0/.

\section{References}

Asam S, Konitzer K, Schieberle P, Rychlik M (2009) Stable isotope dilution assays of alternariol and alternariol monomethyl ether in beverages. J Agric Food Chem 57:5152-5160. https://doi. org/10.1021/jf900450w

Asam S, Liu Y, Konitzer K, Rychlik M (2011) Development of a stable isotope dilution assay for tenuazonic acid. J Agric Food Chem 59:2980-2987. https://doi.org/10.1021/jf104270e 
Asam S, Lichtenegger M, Muzik K, Liu Y, Frank O, Hofmann T, Rychlik M (2013) Development of analytical methods for the determination of tenuazonic acid analogues in food commodities. J Chromatogr A 1289:27-36. https://doi.org/10.1016/j.chroma.2013.03.015

Bauer JI, Gross M, Gottschalk C, Usleber E (2016) Investigations on the occurrence of mycotoxins in beer. Food Control 63:135-139. https://doi.org/10.1016/j.foodcont.2015.11.040

Bottalico A, Logrieco A (1998) Toxicogenic Alternaria species of economic importance. In: Sinha KK, Bhatnagar D (eds) Mycotoxins in Agriculture and Food Safety. Marcel Dekker, Inc, New York, pp 65-108

Broggi L, Reynoso C, Resnik S, Martinez F, Drunday V, Bernal AR (2013) Occurrence of alternariol and alternariol monomethyl ether in beverages from the Entre Rios Province market, Argentina. Mycotoxin Res 29:17-22. https://doi.org/10.1007/s12550-012-0147-6

Cole RJ, Schweikert MA, Jarvis BB (2003) Handbook of secondary fungal metabolites 3 1st Edition Academic Press Elsevier Science, Oxford 45-47

EFSA - European Food Safety Authority (2011) Scientific opinion on the risks for animal and public health related to the presence of Alternaria toxins in feed and food. EFSA Journal 9:2407. https:// doi.org/10.2903/j.efsa.2011.2407

Fan C, Cao X, Liu M, Wang W (2016) Determination of Alternaria mycotoxins in wine and juice using ionic liquid modified countercurrent chromatography as a pretreatment method followed by high-performance liquid chromatography. J Chromatogr A 1436:133-140 https://doi.org/10.1016/j.chroma.2016.01.069

Fleck SC (2014) In vitro-Studien zum genotoxischen Potential und zum Metabolismus von Mykotoxinen mit Resorcylsäurelaktonund Perylenchinon-Struktur. Karlsruher Institut für Technologie, KIT, Dissertation 2013 KIT Scientific Publishing Karlsruhe, Baden https://doi.org/10.5445/KSP/1000039461

Frank O, Kreissl JK, Daschner A, Hofmann T (2014) Accurate determination of reference materials and natural isolates by means of quantitative (1)H NMR spectroscopy. J Agric Food Chem 62:2506-2515. https://doi.org/10.1021/jf405529b

Gotthardt M, Kanawati B, Schmidt F, Asam S, Hammerl R, Frank O, Hofmann T, Schmitt-Kopplin P, Rychlik M (2020) Comprehensive analysis of the Alternaria mycobolome using mass spectrometry based metabolomics. Mol Nutr Food Res 64:1900558. https:// doi.org/10.1002/mnfr.201900558

Habler K, Hofer K, Geißinger C, Schüler J, Hückelhoven R, Hess M, Gastl M, Rychlik M (2016) Fate of Fusarium toxins during the malting process. J Agric Food Chem 64(6):1377-1384. https:// doi.org/10.1021/acs.jafc.5b05998

Habler K, Geißinger C, Hofer K, Schüler J, Moghari S, Hess M, Gastl M, Rychlik M (2017) Fate of Fusarium toxins during brewing. J Agric Food Chem 65:190-198. https://doi.org/10.1021/acs. jafc.6b04182

Liu Y, Rychlik M (2015) Biosynthesis of seven carbon-13 labeled Alternaria toxins including altertoxins, alternariol, and alternariol methyl ether, and their application to a multiple stable isotope dilution assay. Anal Bioanal Chem 407:1357-1369. https://doi. org/10.1007/s00216-014-8307-5

Logrieco A, Moretti A, Solfrizzo M (2009) Alternaria toxins and plant diseases: an overview of origin, occurrence and risks. World Mycotoxin J 2:129-140. https://doi.org/10.3920/WMJ2009.1145

MacLeod L, Evans E (2016) Barley: malting. In: Wrigley CW, Corke H, Seetharaman K, Faubion J (eds.) Encyclopedia of food grains, volume 3, second edition. Elsevier Academic Press, Amsterdam, Boston, Heidelberg, pp 423-428

Mandel J (1964) The statistical analysis of experimental data, Interscience Publishers, a division of John Wiley \& Sons Inc. London, Sydney, New York, pp 160-192

Ostry V (2008) Alternaria mycotoxins: an overview of chemical characterization, producers, toxicity, analysis and occurrence in foodstuffs. World Mycotoxin J 1:175-188. https://doi.org/10.3920/ WMJ2008.x013

Prelle A, Spadaro D, Garibaldi A, Gullino ML (2013) A new method for detection of five Alternaria toxins in food matrices based on LC-APCI-MS. Food Chem 140:161-167. https://doi. org/10.1016/j.foodchem.2012.12.065

Puangkham S, Poapolathep A, Jermnak U, Imsilp K, Tanhan P, Chokejaroenrat C, Poapolathep S (2017) Monitoring and health risk of mycotoxins in imported wines and beers consumed in Thailand. World Mycotoxin J 10:401-409. https://doi. org/10.3920/WMJ2017.2216

Puntscher H, Kütt ML, Skrinjar P, Mikula H, Podlech J, Fröhlich J, Marko D, Warth B (2018) Tracking emerging mycotoxins in food: development of an LC-MS/MS method for free and modified Alternaria toxins. Anal Bioanal Chem 410(18):4481-4494. https://doi.org/10.1007/s00216-018-1105-8

Scheibenzuber S, Hoffmann T, Effenberger I, Schwab W, Asam S, Rychlik M (2020) Enzymatic synthesis of modified Alternaria mycotoxins using a whole-cell biotransformation system. Toxins 12(4):264. https://doi.org/10.3390/toxins 12040264

Siegel D, Merkel S, Koch M, Nehls I (2010) Quantification of the Alternaria mycotoxin tenuazonic acid in beer. Food Chem 120:902-906. https://doi.org/10.1016/j.foodchem.2009.10.070

Soukup ST, Kohn BN, Pfeiffer E, Geisen R, Metzler M, Bunzel M, Kulling SE (2016) Sulfoglucosides as novel modified forms of the mycotoxins alternariol and alternariol monomethyl ether. J Agric Food Chem 64:8892-8901. https://doi.org/10.1021/acs. jafc.6b03120

Visconti A, Sibilia A (1994) Alternaria toxins. In: Miller JD, Trenholm HL (eds) Mycotoxins in grain: compounds other than aflatoxins, Eagan Press, St. Paul, Minnesota, pp 315-336

Vogelgesang J, Hädrich J (1998) Limits of detection, identification and determination: a statistical approach for practitioners. Accredit Qual Assur 3:242-255. https://doi.org/10.1007/s007690050234

Walravens J, Mikula H, Rychlik M, Asam S, Ediage EN, Di Mavungu JD, van Landschoot A, Vanhaecke L, Saeger SD (2014) Development and validation of an ultra-high-performance liquid chromatography tandem mass spectrometric method for the simultaneous determination of free and conjugated Alternaria toxins in cereal-based foodstuffs. J Chromatogr A 1372:91-101. https://doi.org/10.1016/j.chroma.2014.10.083

Walravens J, Mikula H, Rychlik M, Asam S, Devos T, Njumbe Ediage E, Di Diana MJ, Jacxsens L, van Landschoot A, Vanhaecke L, Saeger SD (2016) Validated UPLC-MS/MS methods to quantitate free and conjugated Alternaria toxins in commercially available tomato products and fruit and vegetable juices in Belgium. J Agric Food Chem 64(24):5101-5109. https://doi.org/10.1021/ acs.jafc.6b01029

World Health Organization (WHO) (2018) Global status report on alcohol and health 2018. Chapter 3: alcohol consumption. Pozynak V, Rekve D (eds.) World Health Organization, Geneva, Licence: CC BY-NC-SA 3.0 IGO, pp. 38-47

Zachariasova M, Cajka T, Godula M, Malachova A, Veprikova Z, Hajslova J (2010) Analysis of multiple mycotoxins in beer employing (ultra)-high-resolution mass spectrometry. Rapid Commun Mass Spectrom 24:3357-3367. https://doi.org/10.1002/ rcm.4746

Zwickel T, Klaffke H, Richards K, Rychlik M (2016) Development of a high performance liquid chromatography tandem mass spectrometry based analysis for the simultaneous quantification of various Alternaria toxins in wine, vegetable juices and fruit juices. J Chromatogr A 1455:74-85. https://doi.org/10.1016/j. chroma.2016.04.066 